\title{
Sağlık Personeli ve Öğrencilerin Akılcı İlaç Kullanımı Üzerine Tutum ve Davranışlarının Değerlendirilmesi
}

\section{Evaluation of Knowledge, Attitudes, and Behaviors of Healthcare Workers and Students on Rational Drug Use}

\author{
${ }^{1}$ İlknur ESEN YILDIZ, ${ }^{2}$ Ayten YILMAZ YAVUZ \\ ${ }^{1}$ Recep Tayyip Erdogan University Infectious Diseases and Clinical Microbiology Department \\ ${ }^{2}$ Recep Tayyip Erdogan University Health College Public Health Nursing Department
}

İlknur Esen Y1ldız: https://orcid.org/0000-0003-2987-0483

Ayten Y1lmaz Yavuz : https://orcid.org/0000-0002-5861-4254

\section{ÖZ}

Amaç: Tüm dünyada olduğu gibi ülkemizde de akılcı olmayan ilaç kullanımı önemli sağlık sorunlarından bir tanesidir. Çalışmamız, bir eğitim araştırma hastanesindeki sağlık çalışanlarının ve öğrencilerin akılcı ilaç kullanımı konusundaki bilgi, tutum ve davranışlarını incelemeyi amaçlamıştır.

Materyal ve Metot: Bu kesitsel çalışma için örneklem seçilmedi. Toplam 748 çalışma katılımcısına yüz yüze anket uygulanmıştır. Verileri tanımlayıcı istatistikler ve ki -kare testleri ile analiz ettik.

Bulgular: Sağlık çalışanları ve öğrenciler arasında, doktorlar \% 87,2 ile akılcı ilaç kullanımı konusunda en eğitimli grup olarak bulunmuştur.Ayrıca reçetesiz en çok ilaç alan, gerekli olabileceği düşüncesiyle en fazla ilaç reçetesi yazdırttıran ve gripte en çok antibiyotik kullanan grup da onlardı. Öğrenciler akılcı ilaç kullanımına ilişkin en düşük tutum ve davranış oranına sahipti. Ağrı kesici araştırmaya katılan gruplarda en çok reçete edilen ilaç olarak bulundu. En çok ilaç reçete edilen grup\% 43,8 ile hemşirelerdi.

Sonuç: Sağlık çalışanları ve öğrencilerde, farkındalık eğitimi, eğitimin sürekliliği ve bilginin davranışa dönüştürülmesi planlanmalı ve sağlanmalıdır.

Anahtar Kelimeler: Akılcı ilaç kullanımı, farkındalık, sağlık çalışanı,

\section{ABSTRACT}

Objective: As in the whole world, in our country, too, irrational drug use is one of the importanthealth problems. Our study aimed to examine the knowledge, attitudes, and behaviors of healthcare workersand students in an educational research hospital on rational drug use.

Materials and Methods: For this cross-sectional study, no sample was selected. A face-to-face questionnaire was applied to a total of 748 study participants. We analyzed the data by using descriptive statistics and chi-square tests. Results: Among healthcare workers and students, doctors were found to be the most educated group on rational drug use, with $87.2 \%$. They were also the group, who had been taking the most drugs without a prescription, who had had a drug prescription printed the most with the thought that it might be necessary, and who had used antibiotics the most in flu. Students had the lowest rate of attitude and behavior regarding rational drug use. The analgesics were found to be the most prescribed drug in the surveyed groups. The most drug-prescribed group was nurses, with $43.8 \%$.

Conclusions: Awareness training, continuity of education, and transformation of knowledge into behavior should be planned and ensured in healthcare workers and students.

Keywords: Awareness, healthcare worker, rational drug use
Sorumlu Yazar / Corresponding Author:

İlknur Esen Yildız

Recep Tayyip Erdogan University Infectious Diseases and Clinical Microbiology Department, Rize/Turkey.

Tel: 90 - 04622130491

E-mail: iesenyildiz61@gmail.com
Yayın Bilgisi / Article Info:

Gönderi Tarihi/ Received: 11/06/2020

Kabul Tarihi/ Accepted: 06/07/2020

Online Yayın Tarihi/ Published: 30/09/2020

Atıf / Cited: Esen Yıldız İ and Yılmaz Yavuz A. Evaluation of knowledge, attitudes, and behaviors of healthcare workers and students on rational drug use. Online Türk Sağllk Bilimleri Dergisi 2020;5(3):493-502. doi: 10.26453/otjhs.749166 


\section{INTRODUCTION}

Medications have great importance for public health since they protect the individual from the diseases through therapeutic characteristics and misuse of the medications may cause lack or insufficient treatment, development of resistance or increase in mortality as well as morbidity due to development of side effects. ${ }^{1}$ All individuals of a community, including healthcare professionals, should be aware of rational drug use to achieve accurate use and to have the highest benefit from the drugs. ${ }^{2,3}$

World Health Organization (WHO) defined rational drug use (RDU) in a meeting held in Nairobi in 1985 as the body of rules requiring that patients receive medications appropriate to their clinical needs, in doses that meet their requirements for an adequate period, and the lowest cost to them and their community. ${ }^{4}$ Another definition of RDU is body of principles for the use of an accurate drug, with required doses through accurate and timely administration by sufficient information and considering the cost. ${ }^{4}$

Treatment of a disease may remain deficient; side effects may develop due to irrational drug use; disability or death may develop due to insufficient treatment. Antibiotics are the main focus of irrational drug use. Use of antibiotics for inaccurate causes, mode of administration, dose as well as period may cause colonization by resistant bacteria strains. ${ }^{5} \mathrm{De}-$ velopment of resistance may spread and cause a hazard for other individuals of the community. ${ }^{6}$ Inaccurate use of an antibiotic may cause the development of resistance for other antibiotics. Consequently, infections that are difficult and costly to treat may develop, and the country economy may be damaged. Wrong use of the resources may cause difficulties for the public to access such novel therapies. $^{7}$

More than half of all medications are prescribed inappropriately and used inaccurately. This situation which results with therapy failure and unnecessary consumption of the resources also counts for our country. $^{7}$

Along with the importance of rational drug use, a multifactorial process in terms of the individual and public health, the manifestation of knowledge and attitudes of healthcare professionals would guide future improvements. The present study aimed to determine the attitudes and behaviors of healthcare professionals on rational drug use.

\section{MATERIALS AND METHODS}

Before the onset of the research, written consent from the institution where the research is carried and approval of Ethical Board for Non-interventional Clinical Researches within (Date: 30.03.2018, decision no: 40465587-71). Furthermore, the participants were informed about the research and preserving the confidentiality of their individual information; volunteers were involved in the research.

This cross-sectional study was conducted during the 2017-2018 academic year. The research universe consisted of 1470 participants including 500 students in medical school and 300 students in nursing school in a Medical School and Vocational Health School as well as 350 physicians and 320 nurses who actively work in a Training and Research Hospital in a province of Eastern Black Sea region. The sample size was estimated as 747 participants with universe representative ratio by $80 \%$, in a confidence interval of $99.99 \%$ and a significance level of 0.05 . The number of the participants to be gathered from training and research hospital, medical school and vocational high school of health were determined in proportion to weights of the institutions in the universe; and they were selected by stratified sampling method. The participants who accepted to participate in the research were selected through improbable random sampling method.

The inclusion criteria were being a student in medical and nursing school who actively continue training in Medical School and Nursing School as well as physician and nurse in the Training and Research Hospital and accepting to participate into the study. Data collection was performed through personal interviews and questionnaire forms. The questionnaire form consists of questions on overall attitudes and behaviors of the participants about rational drug use, attitudes and behaviors of the participants about a particular disease, and knowledge level on rational drug use in case of a disease.

Data Collection Tools: Data were collected through personal questionnaire form to determine socio-demographic characteristics and views of the participants on "Rational Drug Use".

Statistical Analysis: Data of the present research was evaluated by SPSS 18.0 for Windows software (SPSS Inc., Chicago, IL, USA). The categorical variables were expressed as number and percentage, the continuous variables were expressed as mean and standard deviation (SD), and compared with Chisquare or Fisher Exact test where appropriate. Statistical significance level was accepted as $p<0.05$. The 
present research was limited with those providing tertiary healthcare services as well as medical school and nursing school students in the Eastern Black Sea region.

\section{RESULTS}

The mean age of the participants was $24.00 \pm 7.15$ (min:17, max:58); $73.1 \%$ of them were single, $58.0 \%$ were female, $34.0 \%$ were the student, and $44.4 \%$ were from Black Sea region. Mean working/ training time was $2.00 \pm 1.76$ (min: 1 , max:25) years. It was detected that $84.8 \%$ of the participants were not diagnosed with any chronic disease; however, $82.5 \%$ of those have a regular drug use state (Table 1).

Review of general attitudes and behaviors of the participants on rational drug use; the difference between the groups in terms of the mean number of medications boxes which is not used or half used, purchasing non-prescription drugs, checking if the drug received matches with one on the prescription, having drugs prescribed or purchasing drugs without any disease, or condition for consideration of further needs and drug use by suggestions of the neighbours/relatives was statistically significant $(p<0.05)$. It was detected that medical school students keep the remaining medications after the treatment most (79.3\%) and they have five boxes or more unused or half-used medications kept $(54.3 \%)$ at home; this group was followed by the physicians. Nursing students $(20.7 \%)$ established the group that disposed of more than five boxes of medications most because of expiration every year.

During reuse of the drug, the physicians have the highest rate of consulting to a physician by $51.9 \%$; the physician group also presented higher rates for purchasing non-prescription drugs and prescription of drugs without any disease for further need considerations by $51.9 \%$ and $44.1 \%$, respectively.

The most common drug prescribed in all groups was analgesics; nursing students presented the highest prescription rates $(43.8 \%)$. The group which requested prescription of antibiotics due to the possibility of need in the future was the physicians by $11.3 \%$. Such rate was considerable when compared with other groups.

Nurses had the highest rate $(65.0 \%)$ for taking medications with them when they needed to leave home for a short period (Table 2).

Review of attitudes and behaviors of the participants on rational drug use revealed that there was a statistically significant difference between the groups in terms of use of the medications prescribed by the physician, antibiotic use in flu, cold and influenza without being examined $(p<0.05)$; however, the difference for informing the physician about previously used drugs and history of chronic diseases, informing the physician and concerning healthcare professionals about food or drug allergy during the examination and use of vitamin and mineral supplementation regularly was not statistically significant between the groups ( $>>0.05)$. However, the use of antibiotics for flu, cold, influenza without being examined was considerably higher in the physician group by $29.1 \%$ when compared with other groups (Table 3).

Review of the distribution of knowledge level of the participants on rational drug use in case of disease revealed that there is a statistically significant difference on thoughts about participating in briefings about rational drug use and effect of mode of administration on treatment success between the groups $(\mathrm{p}<0.05)$.

Participation in briefing training about rational drug use was detected in the physician group and the nurse group by $87.2 \%$ and $80.5 \%$, respectively. Both groups reported that they obtained information mostly from the lectures during education. Highest rates on participation into occupational courses and in-house training meetings were detected in the aforementioned groups. Investigation of the knowledge level about medication asserted that administration method, duration of action, side effects, contraindications, drug interactions, specific conditions for the drug were highest in the physician group; such rate was detected less in the student groups. Consideration of the importance of physician's suggestions on the effect of administration method of the drug on treatment success was highest in the medical school students by $61.4 \%$ whereas consideration of the effectiveness of administration method was highest in the physician group. Reviewing the package insert of medication about learning drug use, as well as possible adverse events, was higher in the nursing students $(56.9 \%)$ and the nurses $(55.8 \%)$. The attitude to refer a physician in case of any side effect was highest in the nurse group by $85.7 \%$ (Table 4).

\section{DISCUSSION AND CONCLUSION}

More than half of all medications all over the world were inappropriately prescribed and inaccurately used by the patients. This situation which results with therapy failure and unnecessary consumption 
of the resources also counts for our country. Different studies show that drug consumptions, as well as commonly consumed drugs, are not parallel with the disease burden in our country and all over the world. ${ }^{8}$ This requires to address rational drug use in particular. There are many forms of inappropriate drug use. Inattentive behavior on drug use (administration method, period, dose), unnecessary antibiotic use, excessive and multiple drug use, selection of treatment which is not compliant to clinical guidelines, inadequate selection of the medications newly introduced to the market, inadequate injection treatment, unnecessary and inadequate use of vitamins and analgesics, unaware use of herbal products, ignorance of drug-drug and drug-food interactions are inadequate drug use. 5, 9

Review of general attitudes and behaviors of the participants on rational drug use asserted that although students mostly care about the adequacy and expiry date of the medications at home, eight of ten medical students keep remaining drugs to be used when necessary and one of every two students have more than five boxes of unused or half-used medications. Use of drugs with recommendations of the neighbors and relatives was highest in the student group. Furthermore, the rate of consulting to a physician during reuse was found lower in both student groups. Rational drug use is detected lower in the students in general. The cause of lower rates among the students may be lack of implementation experience among the students since they have mainly consisted of medical students who did not start internship and pharmacology course is given in the second grade in nursing school.

This sets to think that theoretical training of medical school and nursing school students is not transformed into behavior. Addition of RDU courses into the curriculum and internship program from 4th grade along with theoretical medical training to adopt RDU skills, following with measurement and assessment methods to provide transformation into behavior and providing surveillance of rational drug use training may be recommended. Previous studies indicated that training for RDU that shall be provided for the students, especially during clinical practice is effective to increase the awareness and to transform into behavior.

From the view of rational drug use, it is observed that more than half of physicians consult to a physician during reuse of the drug; and they have medications prescribed due to possible need in the future without any current disease. Previous studies indi- cate that information on medication are gathered from different sources of information such as vademecum, medical representatives, articles and internet; and such information is implemented depending on self-knowledge and experience. ${ }^{10-12}$ Although the consulting rate was the highest among the physicians by $51.9 \%$, this undesired rate level may be associated with the fact that physicians utilize other sources of information for the drug and higher selfconfidence levels. Since the physicians have the highest rate of purchasing non-prescription drugs and having drugs prescribed even they are not necessary, the importance of training for awarenessraising appears in the physician group which is expected to have the highest rate of awareness.

The most common non-prescription drug was analgesics in all groups. Similarly, previous studies report that analgesics are the most common medications prescribed by the physician upon request. ${ }^{13-15}$ In consideration of the mechanism of action, such medications may suppress the symptoms and findings of disease and cause misdiagnose, treatment difficulties and complications. Not only analgesics, but all medications should also be used under the supervision of a physician. Self-treatment attempts of an individual may cause different damages in the body. Since many factors, including metabolic situations, underlying diseases, genetic differences, allergy states, co-morbidities of the individuals may affect the treatment, non-prescription drug use should be avoided. $^{7}$

One of the most important samples of irrational drug use is unnecessary use of antibiotics. Although it is known that antibiotics are effective in bacterial infections only, unnecessary use of antibiotics is common in our country and globally. Antibiotics are not effective for anything other than bacterial infections and may cause antibiotic resistance and treatment difficulties. The spread of the resistance may cause a hazard for other individuals of the community. The most important risk group consists of the individuals who had organ transplantation, surgical procedures such as prosthesis surgery, intensive care patients, those receiving chemotherapy and premature babies. ${ }^{7}$ The present study found that physicians had the highest rates on prescribing antibiotics due to possible necessity by $11.3 \%$ and one of each three physicians use antibiotics in case of flu and cold, which are viral infections. Such a significant increase in irrational drug use in the physician group of which the awareness should be the best when compared with other groups reveal the requirement 
of awareness-raising. The situation is similar in other individuals of society. A previous study conducted in our country reported that $15.6 \%$ of the population had unnecessary antibiotics. ${ }^{13}$ Rate of antibiotic use is in the first rank by $34.5 \%$ when compared with other countries of the world. It should be noted that we have responsibilities on drug use, including antibiotics to avoid any possible resistant infections which are difficult or impossible to treat. Awareness of all individuals of the population, including healthcare professionals, in particular, should be raised. $^{5}$

Compliance to the period determined by the physician is essential for drug therapy. The rates on the aforementioned component were found lower in the nurse and student groups in the present study. It is concluded that awareness studies should be planned especially in these groups. This may be associated with deficient sensibility and knowledge of the nurses and students as well as clinical relief when symptoms disappeared. Besides, we think that the low rate of participation in information education on rational drug use in this study may affect.

Since information on RDU is mostly obtained from the lectures during education period and lowest rates of participation into professional courses and inhouse training meetings were detected in the student groups, this makes clear the requirement of studies to be planned to provide participation of the students. Investigation of the knowledge level about medication asserted that administration method, duration of action, side effects, contraindications, drug interactions, specific conditions for the drug were highest in the physician group; such rate was detected less in the student groups. The highest rates in consideration of the importance of physician's suggestion for drug administration method on treatment success in the physician group may be explained with the increase in awareness level for medications due to prescribing medications in clinical practice. Participation of the students and nurses should be achieved to increase such rate and transformation of theoretical information into behavior should be provided.

In the present study, package insert reading to learn about usage and possible adverse events was higher in the nursing students and nurses by $56.9 \%$ and $55.8 \%$, respectively. It was found in the study of Sahingoz and Balc1, that nurses learn information about the medications from vademecum by $87.5 \%$ and use package inserts of the drugs by $75.7 \%{ }^{16}$.
The nurse group presented the highest rates for referring a physician in case of development of adverse events by $90.2 \%$ in the present study. Since the nurses are healthcare professionals who administer the medications and closely monitor the treatment outcomes, awareness on side effects may be related to the knowledge on the necessity of drug changing in case of a side effect. Results are similar in the studies conducted in our country; it was reported that eight of ten nurses refer to a physician in case of a drug side effect. ${ }^{17}$

As a result; role of society on rational drug use is quite remarkable. The aim should be to prevent treatment problems, to be able to increase treatment success and to be able to prevent the development of resistant infections which are difficult and costly to treat. Each individual of the society including healthcare professionals, in particular, has a responsibility to make rational drug use common to be able to contribute to the country economy by providing efficient treatment of the individual to reintegrate to the society and avoiding unnecessary drug use. Enabling sensitivity and awareness of the physicians and nurses who actively act in the identification of the health problem of the individual, planning and conducting the adequate treatment on rational drug use would be effective to increase the quality of life of the individuals. In this context, planning for training on rational drug use may be considered in collaboration with training institutions and hospitals. Furthermore, we believe that achieving sustainability of the training, increasing participation if healthcare professionals and carrying out studies for awareness rising would contribute to consciousness on rational drug use.

Ethics Committee Approval: Our study was approved by the Non-Interventional Clinical Research Ethics Committee (Date: 30.03.2018, decision no: 40465587-71).

Conflict of Interest: No conflict of interest was declared by the authors.

Author Contributions: Concept - IEY; Supervision - IEY; Materials - IEY, AYY; Data Collection and/ or Processing - IEY, AYY; Analysis and/ or Interpretation - AYY; Writing -, IEY.

Peer-review: Externally peer-reviewed.

\section{REFERENCES}

1. Hogerzeil HV, BarnesK, Henning RH, et al. Teacher's Guide to Good Prescribing. World 
Health Organization, Department of Essential Drugs and Medicines Policy, 2001.http:// digicollection.org/hss/en/d/Js2292e/4.html. Erişim tarihi 25 Nisan 2020.

2. Aydin B, GelalA. Extentification of RationalDrugUseand Role of Medical Training. Dokuz Eylül University Faculty of Medicine. 2012;26(1):5763.

3. Surmelioglu N, KırogluO, Erdogdu T, Karatas Y. Precautions to Prevent Irrational Drug Use. Archives Medical Review Journal. 2015;24(4):452462.

4. WHO, Therationaluse of drugs Report of the Conference of Experts Nairobi. World HealthorganizationGeneva, 1987.https://apps.who.int/iris/ handle/10665/37174. Erişim tarihi 25 Nisan 2020.

5. WHOReport. HealthSystemsFinancing: ThePathto Universal Coverage, Achieving Better Health Outcomes And Efficiency Gains Through Rational Use Of Medicine. Technical Brief SeriesBrief No 3, 2010. https://apps.who.int/iris/ bitstream/ handle/10665/44371/9789241564021_eng.pdf? sequence $=1$. Erişim tarihi 25 Nisan 2020 .

6. Aksoy M, Alkan A, İşli F. Extentification activities of ministry of health on rational drug use.Turkish Clinics J Pharmacol-Special Topics. 2015;3(1):19-26.

7. WHO, The World Health Report: Health Systems Financing. Thepathtouniversalcoverage, 2010.https://www.who.int/whr/2010/en/. Erişim tarihi 25 Nisan 2020.

8. Sayg1lı M, Özer Ö. An Evaluation on Knowledge, AttitudeandBehaviors of Physicians on RationalDrugUse. Hacettepe Health Management Journal. 2015;18(1):35-46.

9. Republic of Turkey. Ministry of Health.Turkish Medicines and Medical Devices Agency. Rational Antibiotic Use. https://www.titck.gov.tr/ Dosyalar/Erisim/TMMDABrochure.pdf. Erişim tarihi 25 Nisan 2020.

10. Başaran NF, Akıcı A. Aspects of Physicians' Attitudes Towards the Rational Use of Drugs at a Training and Research Hospital: A Survey Study. European Journal of Clinical Pharmacology. 2013;69(8):1581-1587.

11. Mahajan R, Singh N, Singh J, Dixit A, Jain A, Gupta A. CurrentScenario of Attitudeand Knowledgeof Physicians About Rational Prescription: A Novel Cross-Sectional Study. Journal of Pharmacy and BioAllied Sciences. 2010;2 (2):132-136.
12. Prosser H, AlmondS, Walley T. Influences on GPs' Decision to Prescribe New Drug-The Importance of Who Says What Family Practice. Fam Pract. 2003;20(1):61-68.

13. Ekenler Ş, Kocoglu D. Knowledge andPractice of the Individuals on Rational Drug Use. HacettepeUniversityNursing Faculty Journal. 2016;3 (3):44-55.

14.İlhan MN, Aydemir Ö, Cakır M, Aycan S. Behaviors on irrational drug use: A sample of three districts in Ankara. Turkish Public Health Journal. 2014;12(3):188-200.

15.Uskun E, UskunS, Ozturk M, Kisioglu AN. Drug use before referral to medical center. Sustained Medicine Training Journal. 2004;13(12):451454.

16. Ozcelikay G. A Pilot Study on rational DrugUse. Ankara Faculty of Pharmacy Journal. 2001;30 (2):9-18. 
Table 1. Distribution of descriptive characteristics of the participants.

\begin{tabular}{|c|c|c|c|}
\hline & & $\mathbf{n}$ & $\%$ \\
\hline Characteristics & & \multicolumn{2}{|c|}{ Mean \pm SD } \\
\hline Age & & \multicolumn{2}{|c|}{$24.00 \pm 7.15(\min : 17, \max : 58)$} \\
\hline \multirow[t]{2}{*}{ Gender } & Female & 434 & 58.0 \\
\hline & Male & 314 & 42.0 \\
\hline \multirow{7}{*}{ Hometown } & Central Anatolia Region & 130 & 17.4 \\
\hline & Black Sea Region & 332 & 44.4 \\
\hline & Mediterranean Region & 81 & 10.8 \\
\hline & Aegean Region & 74 & 9.9 \\
\hline & Eastern Anatolia Region & 67 & 9.0 \\
\hline & Southeastern Anatolia Region & 28 & 3.7 \\
\hline & Marmara Region & 36 & 4.8 \\
\hline \multirow[t]{4}{*}{ Profession } & Physician & 180 & 24.1 \\
\hline & Nurse & 164 & 21.9 \\
\hline & Medical school student & 254 & 34.0 \\
\hline & Nursing school student & 150 & 20.1 \\
\hline Working/ & Education year & \multicolumn{2}{|c|}{$2.00 \pm 1.76(\min : 1, \max : 25)$} \\
\hline \multirow[t]{2}{*}{ Marital status } & Married & 191 & 25.5 \\
\hline & Single & 547 & 73.1 \\
\hline \multirow[b]{2}{*}{ Regular drug use } & Yes & 131 & 17.5 \\
\hline & No & 617 & 82.5 \\
\hline \multirow[b]{2}{*}{ Chronic disease } & No disease/disorder & 634 & 84.8 \\
\hline & Any disease/disorder & 114 & 15.2 \\
\hline
\end{tabular}


Table 2. Attitudes and behavors of the participants on rational drug use in case of any disease.

\begin{tabular}{|c|c|c|c|c|c|}
\hline \multirow[t]{2}{*}{$\begin{array}{l}\text { Attitudes and behaviors on rational drug } \\
\text { use in case of a disease }\end{array}$} & Physician & Nurse & $\begin{array}{c}\text { Student } \\
\text { (Medicine) }\end{array}$ & $\begin{array}{c}\text { Student } \\
\text { (Nursing) }\end{array}$ & \multirow[t]{2}{*}{$\begin{array}{l}\text { Test and } \\
\text { p-value }\end{array}$} \\
\hline & $\mathrm{n}(\%)$ & $\mathrm{n}(\%)$ & $\mathrm{n}(\%)$ & $\mathrm{n}(\%)$ & \\
\hline \multicolumn{6}{|c|}{ While using adrug in case of a medical condition** } \\
\hline Consulting to a physician & $158(79.8)$ & 143(65.9) & $210(67.1)$ & $109(58.9)$ & \\
\hline Consulting to a pharmacist & $3(1.5)$ & $7(3.2)$ & $7(2.2)$ & $8(4.3)$ & \\
\hline Consulting to a neighbor/relative & - & $1(0.5)$ & $9(2.9)$ & $5(2.7)$ & \\
\hline Consulting to other healthcare staff & - & $15(6.9)$ & $10(3.2)$ & $17(9.2)$ & \\
\hline Trying herbal remedies & $8(4.0)$ & $28(12.9)$ & $26(8.3)$ & $24(13.0)$ & \\
\hline Trying to be treated by the drugs at home & $16(8.1)$ & $16(7.4)$ & $31(9.9)$ & $12(6.5)$ & \\
\hline $\begin{array}{l}\text { Asking those who had similar conditions be- } \\
\text { fore }\end{array}$ & - & $3(1.4)$ & $14(4.5)$ & $5(2.7)$ & \\
\hline Other & $13(6.6)$ & $4(1.8)$ & $6(1.9)$ & $5(2.7)$ & \\
\hline \multicolumn{6}{|c|}{ Informing the physician about previous medications used and chronic diseases diagnosed at referral } \\
\hline Yes & $168(94.4)$ & $\begin{array}{c}149 \\
(93.1)\end{array}$ & $234(93.2)$ & $139 / 92.7$ & $\begin{array}{l}X^{2}=0.43 \\
8\end{array}$ \\
\hline No & $10(5.6)$ & $11(6.9)$ & $17(6.8)$ & $11(7.3)$ & 0.932 \\
\hline \multicolumn{6}{|c|}{$\begin{array}{l}\text { Informing the physician and concerning healthcare professional about food or drug allergy during an } \\
\text { examination }\end{array}$} \\
\hline Yes, informing & $169(93.9)$ & $\begin{array}{c}150 \\
(91.5)\end{array}$ & $233(91.7)$ & $140(93.3)$ & $\mathrm{X}^{2}=1.22$ \\
\hline No, not informing & $11(6.1)$ & $14(8.5)$ & $21(8.3)$ & $10(6.7)$ & 0.772 \\
\hline \multicolumn{6}{|l|}{ Use of the drugs prescribed by the physician* } \\
\hline Use of the drug completely & $38(21.7)$ & $31(19.9)$ & $36(14.3)$ & $20(13.5)$ & $\begin{array}{l}X^{2}=28,2 \\
59\end{array}$ \\
\hline Using until the complaints resolve & $23(13.1)$ & $45(28.8)$ & $83(32.9)$ & $52(35.1)$ & $<0.001$ \\
\hline Using within suggested period & $114(65.1)$ & $80(51.3)$ & $133(52.8)$ & $76(51.4)$ & \\
\hline \multicolumn{6}{|c|}{ Use of antibiotics for flu, cold, influenza without being examined* } \\
\hline Yes, I use & $51(29.1)$ & $18(11.2)$ & $40(15.9)$ & $20(13.5)$ & $\begin{array}{l}X^{2}=28,2 \\
45\end{array}$ \\
\hline I start and I discontinue when I feel better & $8(4.6)$ & $9(5.6)$ & $26(10.4)$ & $14(9.5)$ & $<0.001$ \\
\hline No, I do not use without examination & $116(66.3)$ & $\begin{array}{c}134 \\
(83.2) \\
\end{array}$ & $185(73.7)$ & $114(77.0)$ & \\
\hline
\end{tabular}

*Column percentage gets **Percentages were calculated over multiple answers, and column percentage was get. 
Table 3. Distribution of knowledge level of the participants on rational drug use in case of a disease-1.

\begin{tabular}{|c|c|c|c|c|c|}
\hline \multirow[t]{2}{*}{ Knowledge level on rational drug use } & Physician & Nurse & $\begin{array}{c}\text { Student } \\
\text { (Medicine } \\
\text { ) }\end{array}$ & $\begin{array}{l}\text { Student } \\
\text { (Nursing) }\end{array}$ & $\begin{array}{l}\text { Test and } \\
\text { p-value }\end{array}$ \\
\hline & $\mathrm{n}(\%)$ & $\mathrm{n}(\%)$ & $\mathrm{n}(\%)$ & $\mathrm{n}(\%)$ & \\
\hline \multicolumn{6}{|c|}{ Participation in briefing training about rational drug use* } \\
\hline Yes & $157(87.2)$ & $132(80.5)$ & $189(74.5)$ & $86(57.3)$ & $\begin{array}{l}X^{2}=42,38 \\
4\end{array}$ \\
\hline No & $23(12.8)$ & $32(19.5)$ & $65(25.6)$ & $64(42.7)$ & $<0.001$ \\
\hline \multicolumn{6}{|c|}{ Holder (individual/organization) of the briefing meeting about rational drug use** } \\
\hline From lectures during education period & $99(44.4)$ & $72(37.5)$ & $146(64.6)$ & $60(54.59$ & \\
\hline In-house training meetings & $76(34.1)$ & $65(33.9)$ & $42(18.6)$ & $17(15.5)$ & \\
\hline From official website of Ministry of health & $13(5.8)$ & $13(6.8)$ & $4(1.8)$ & $13(11.8)$ & \\
\hline Internet/press/radio/newspaper & $8(3.6)$ & $17(8.9)$ & $28(12.4)$ & $16(14.5)$ & \\
\hline Occupational courses & $24(10.8)$ & $21(10.9)$ & $4(1.8)$ & $2(1.8)$ & \\
\hline Pharmaceutical companies & $3(1.3)$ & $4(2.1)$ & $2(0.9)$ & $2(1.8)$ & \\
\hline \multicolumn{6}{|c|}{$\begin{array}{l}\text { Rendition of knowledge level about the medications used for any medical condition as very } \\
\text { good** }\end{array}$} \\
\hline Purpose of use* & $92(30.9)$ & $65(21.8)$ & $82(32.3)$ & $59(19.8)$ & \\
\hline Administration method & $95(28.0)$ & $83(24.5)$ & $88(26.0)$ & $73(21.5)$ & \\
\hline Action time & $71(37.0)$ & $48(25.0)$ & $34(17.7)$ & $39(20.3)$ & \\
\hline Adverse events & $58(38.7)$ & $41(27.3)$ & $27(18.0)$ & $24(16.0)$ & \\
\hline Contraindications & $64(41.3)$ & $37(23.9)$ & $29(18.7)$ & $25(16.1)$ & \\
\hline Drug interactions (drug/food) & $51(39.7)$ & $29(22.1)$ & $23(17.6)$ & $27(20.6)$ & \\
\hline Warning/precautions & $58(33.1)$ & $37(21.1)$ & $42(24.0)$ & $38(21.7)$ & \\
\hline $\begin{array}{l}\text { Special conditions (such as pregnancy, pediatric } \\
\text { age group) }\end{array}$ & $61(33.29$ & $43(23.4)$ & $41(22.3)$ & $39(21.2)$ & \\
\hline
\end{tabular}

*Column percentage gets **Percentages were calculated over multiple answers, and column percentage was get. 
Table 4. Distribution of knowledge level of the participants on rational drug use in case of a disease2.

\begin{tabular}{|c|c|c|c|c|c|}
\hline \multirow[b]{2}{*}{ Knowledge level on rational drug use } & Physician & Nurse & $\begin{array}{c}\text { Student } \\
\text { (Medicine) }\end{array}$ & $\begin{array}{l}\text { Student } \\
\text { (Nursing) }\end{array}$ & $\begin{array}{l}\text { Test and } \\
\text { p-value }\end{array}$ \\
\hline & $\mathrm{n}(\%)$ & $\mathrm{n}(\%)$ & $\mathrm{n}(\%)$ & $\mathrm{n}(\%)$ & \\
\hline \multicolumn{6}{|c|}{ Consideration on the effect of drug administration method on treatment success* } \\
\hline Better treatment with parenteral administration & $26(15.1)$ & $25(16.1)$ & $55(21.9)$ & $48(33.1)$ & $\begin{array}{l}X^{2}=45,82 \\
9\end{array}$ \\
\hline $\begin{array}{l}\text { Those preferring oral administration due to fear } \\
\text { from parenteral administration }\end{array}$ & $8(4.7)$ & $18(11.6)$ & $16(6.4)$ & $8(5.5)$ & $<0.001$ \\
\hline $\begin{array}{l}\text { Those who do not prefer oral administration due } \\
\text { to swallowing difficulty }\end{array}$ & $3(1.7)$ & $7(4.5)$ & $1(0.4)$ & $7(4.8)$ & \\
\hline $\begin{array}{l}\text { Drug administration method is effective on suc- } \\
\text { cess }\end{array}$ & $34(19.8)$ & $16(10.3)$ & $25(10.0)$ & $13(9.0)$ & \\
\hline Suggestion of the physician is important & $101(58.7)$ & $89(57.4)$ & $154(61.4)$ & $69(47.6)$ & \\
\hline \multicolumn{6}{|c|}{ Learning information about drug use and possible adverse events** } \\
\hline Physician & $99(46.5)$ & $54(24.1)$ & $93(27.8)$ & $39(20.7)$ & \\
\hline Pharmacist & $4(1.9)$ & $20(8.9)$ & $35(10.4)$ & $22(11.7)$ & \\
\hline Nurses and other healthcare professionals & - & $13(5.8)$ & $8(2.4)$ & $5(2.7)$ & \\
\hline Package insert of the drug & $86(40.4)$ & $125(55.8)$ & $167(49.9)$ & $107(56.9)$ & \\
\hline Internet & $24(11.3)$ & $12(5.4)$ & $32(9.6)$ & $15(8.0)$ & \\
\hline \multicolumn{6}{|c|}{ Behavior when experienced adverse events of a drug ${ }^{* *}$} \\
\hline Consulting to a physician & $164(85.4)$ & $148(90.2)$ & $221(85.3)$ & $132(85.7)$ & \\
\hline Consulting to a pharmacist & $3(1.6)$ & $4(2.4)$ & $9(3.5)$ & $5(3.2)$ & \\
\hline Consulting a nurse and other healthcare staff & - & $3(1.8)$ & $3(1.2)$ & $8(5.2)$ & \\
\hline Seeking solutions by himself & $23(12.0)$ & $8(4.9)$ & $17(76.6)$ & $6(3.9)$ & \\
\hline Doing nothing & $2(1.0)$ & $1(0.6)$ & $9(3.5)$ & $3(1.9)$ & \\
\hline
\end{tabular}

*Column percentage gets **Percentages were calculated over multiple answers, and column percentage was get. 